\title{
KINERJA KEUANGAN PERUSAHAAN PROPERTI MENGGUNAKAN METODE ZMIJEWSKI
}

\section{FINANCIAL PERFORMANCE OF THE PROPERTY COMPANY USING ZMIJEWSKI METHOD}

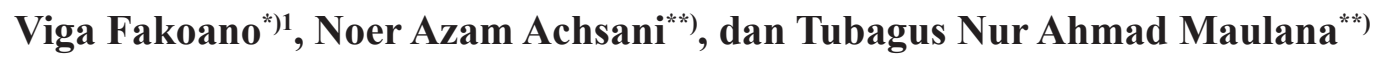 \\ *) PT Infia Media Pratama
}

Jl. H. Syahrin No. 20 RT 01/ 10 Gandaria Utara Kebayoran Baru, Jakarta Selatan 12140

${ }^{* *)}$ Sekolah Bisnis, Institut Pertanian Bogor

Jl. Raya Pajajaran, Bogor 16151

\begin{abstract}
The purpose of this study was to analyze PWON financial distress potential by using the Zmijewski calculation method. Next is to analyze the relationship between financial distress and other independent variables. To calculate the potential of financial distress, the Zmijewski method is used. Microsoft Excel 2010 is used as supporting software in calculating financial distress potential. To calculate the correlation between the dependent and independent variables, Eviews 6 software is used with the method of error correction method. The results of the research obtained are exchange rates, interest rates, operating expenses growth, COGS growth, and DER have a long-term and short-term effect on the value of Zmijewski. PWON's financial performance assessment using the Zmijewski method illustrates that PWON is in a healthy condition throughout the study period. This assessment is based on the Zmijewsi PWON value which is always below 0.5 as the critical value of the Zmijewski method.
\end{abstract}

Keywords: financial distress, pakuwon jati, zmijewski, financial performance, property

\begin{abstract}
Abstrak: Tujuan dari penelitian ini adalah menganalisis potensi financial distress PWON dengan menggunakan metode perhitungan Zmijewski. Selanjutnya adalah untuk menganalisis hubungan antara financial distress dengan variabel-variabel independen lainnya. Untuk menghitung potensi financial distress digunakan metode Zmijewski. Microsoft Excel 2010 digunakan sebagai software pembantu dalam menghitung potensi financial distress. Untuk menghitung korelasi antara variabel dependen dan independen, digunakan software Eviews 6 dengan metode error correction model. Hasil pada penelitian yang didapat adalah kurs, tingkat suku bunga, pertumbuhan beban operasi, pertumbuhan COGS, dan DER memiliki pengaruh jangka panjang dan jangka pendek terhadap nilai Zmijewski. Penilaian kinerja keuangan PWON dengan menggunakan metode Zmijewski menggambarkan bahwa PWON berada dalam kondisi sehat sepanjang periode penelitian. Penilaian ini didasari dari nilai Zmijewsi PWON yang selalu berada dibawah 0,5 sebagai critical value dari metode Zmijewski.
\end{abstract}

Kata kunci: financial distress, pakuwon jati, zmijewski, kinerja keuangan, properti

\footnotetext{
${ }^{1}$ Alamat Korespondensi:

Email: viga.fakoano@gmail.com
} 


\section{PENDAHULUAN}

Potensi kebangkrutan (financial distress) dimiliki oleh setiap perusahaan dan akan memberikan kekhawatiran kepada pihak internal ataupun eksternal (Yuliastary dan Wirakusuma, 2014). Kondisi financial distress perlu diketahui sejak dini sehingga manajemen mampu menentukan tindakan untuk antisipasi yang mengarah pada kebangkrutan (Haryetti, 2010). Financial distress terjadi sebelum kebangkrutan yang sesungguhnya terjadi.

Model perhitungan financial distress telah ada sejak lima dekade yang lalu dan berguna untuk memprediksikan masalah keuangan perusahaan. Model perhitungan tersebut diambil dari laporan keuangan (rasio solvabilitas, aktivitas, profitabilitas, investasi dan leverage) (Sarlija dan Jeger, 2011)

Ada berbagai macam cara untuk menghitung potensi financial distress sebuah perusahaan, salah satunya adalah Metode Zmijewski. Model perhitungan Zmijewski dikembangkan atas dasar perhitungan dari 75 perusahaan yang bangkrut, serta 73 perusahaan yang sehat selama periode tahun 1972-1978. Perhitungan Zmijewski menitikberatkan perhitungan dengan rasio kelompok rate of return, liquidity, leverage, turnover, fixed payment coverage, trends, firm size dan stock return volatility (Yuliastary dan Wirakusuma, 2014).

Kondisi financial distress tidak hanya terjadi karena dampak intern perusahaan. Namun, ada dampak dari ekonomi eksternal (makro ekonomi). Fenomena financial distress di perusahaan publik Indonesia yang ada akhir-akhir ini terjadi ketika peningkatan harga minyak yang mengejutkan pada tahun 2005 dan krisis Subprime mortgage pada tahun 2008 (Pranowo et al. 2010). Pada tahun 2005, pemerintah Indonesia mengurangi subsidi untuk harga minyak lokal. Hal ini membuat biaya produksi mengalami peningkatan dan akhirnya menurunkan profitabilitas perusahaan. Selain itu non-performing loan (NPL) pada bank umum yang meningkat menjadi 68 triliun rupiah pada Maret 2006 dari 61 triliun rupiah pada Oktober 2005. Banyak perusahaan publik yang terdaftar di Bursa Efek Indonesia (BEl) menjadi delisting sebagai akibat dari kerugian besar dan kekurangan uang tunai (Dwijayanti, 2010). Financial distress atau yang berakhir dengan kebangkrutan dapat menyebabkan efek masif bagi shareholders, investor, kreditur, manajer dan pegawai (Salehi dan Abendini, 2009)
Industri properti di Indonesia tidak luput dari potensi kebangkrutan. Subprime mortgage dan pelemahan nilai rupiah pada tahun 2008 diyakini menjadi salah satu penyebab utama efek berantai dari krisis yang dialami secara global. Indonesia menjadi lahan bisnis properti yang terbuka lebar dan masih terus berkembang. Berdasarkan data yang dikeluarkan oleh Knight Frank dalam laporan Global House Price Index ditahun 2013, Indonesia memimpin dengan angka pertumbuhan $11,5 \%$ dibandingkan dengan Malaysia (10,1\%) dan Singapura $(1,9 \%)$ sebagaimana ditunjukan pada Tabel 1. Posisi Indonesia di dunia pun terbilang bagus bila dibandingkan dengan negara Asia Tenggara lainnya. Indonesia berada di posisi ketujuh dari 56 negara yang disurvei oleh Knight Frank.

Dalam laporan Bank Indonesia triwulan IV tahun 2014 dinyatakan bahwa harga dan volume properti residensial di pasar primer pada triwulan IV tahun 2014 menunjukan peningkatan dan diperkirakan akan berlanjut pada tahun 2015. Perlu diketahui, bahwa pasar primer adalah rumah baru atau tangan pertama. Dibandingkan dengan triwulan IV tahun 2013, pertumbuhan harga properti residensial di triwulan IV tahun 2014 meningkat 1,54\%. Namun, bila dibandingkan secara tahunan (yoy), pertumbuhan ini mengalami perlambatan. Perlambatan ini terjadi karena tingkat inflasi mencapai $8,36 \%$. Inflasi ini menyebabkan naiknya harga bangunan dan upah pekerja. Tidak berbeda jauh dengan pasar properti residensial primer, pasar properti sekunder pun mengalami peningkatan penjualan. Di Jakarta, pasar properti sekunder meningkat sebesar 4,12\%.

Tabel 1. Indeks pertumbuhan harga pasar properti global tahun 2012-2013

\begin{tabular}{cll}
\hline Peringkat & Negara & Pertumbuhan \\
\hline 1 & Dubai & $34,8 \%$ \\
2 & China & $27,5 \%$ \\
3 & Taiwan & $15,1 \%$ \\
4 & Estonia & $14,5 \%$ \\
5 & Turki & $13,8 \%$ \\
6 & Brasil & $12,7 \%$ \\
7 & Indonesia & $11,5 \%$ \\
8 & Kolombia & $11,5 \%$ \\
9 & Amerika Serikat & $11,3 \%$ \\
10 & Polandia & $10,2 \%$ \\
\hline
\end{tabular}


Dalam sebuah artikel pada situs www.bankrupt.com yang dikeluarkan oleh Beard Group, PWON mengalami penurunan nilai Moody dari B2 menjadi B3. Hal tersebut dikarenakan pelemahan nilai kredit PWON bila dibandingkan dengan likuiditasnya yang diakibatkan oleh pelemahan permintaan properti, depresiasi nilai rupiah dan ketatnya pasar finansial. Selain itu kegiatan pra-penjualan salah satu produk PWON, yaitu Gandaria City di Jakarta Selatan berada dibawah ekpektasi. Nilai penjualan kondominium hanya $51 \%$ dan $28 \%$ pada perkantoran selama November 2008.

PWON adalah salah satu perusahaan pengembang yang bergerak di bidang real estate di antara 45 emiten yang terdaftar pada Bursa Efek Indonesia sub sektor properti. PWON didirikan pada tahun 1982 dan pada tahun 1989 perseroan melakukan initial public offering atau IPO. PWON merupakan salah satu perusahaan yang termasuk dalam LQ45 di Bursa Efek Indonesia sub sektor properti.

Lebih lanjut dalam artikel tersebut, depresiasi nilai rupiah dapat meningkatkan nilai hutang obligasi PWON dalam bentuk Dollar Amerika. Efek lebih jauhnya adalah depresiasi nilai Rupiah tersebut akan menekan likuiditas PWON pada tahun 2009. Pada tanggal 16 Maret 2009, peringkat Moody PWON pun turun menjadi Caa1 dari B3. Moody investor service menurunkan peringkat tersebut berdasarkan oleh empat faktor, yaitu risiko bisnis dan posisi yang kompetitif antar perusahaan dalam industri yang sama, struktur modal dan risiko keuangan, proyeksi kinerja dalam waktu dekat dan menengah, rekam jejak manajemen dan toleransi terhadap risiko. Keempat faktor tersebut muncul atas dasar perbandingan dengan permasalahan di dalam dan di luar PWON. Pendanaan dengan menggunakan hutang yang terlalu tinggi akan meningkatkan risiko keuangan perusahaan dan pada akhirnya bisa mengakibatkan krisis atau financial distress (Steven dan Lina, 2011). Perbandingan laba setelah pajak dan hutang usaha PWON pada Gambar 1.

Penelitian mengenai potensi kebangkrutan sudah banyak dilakukan diberbagai negara. Banyak penelitian menghubungkan antara variabel mikro dengan variabel makro untuk mengetahui potensi kebangkrutan sebuah perusahaan atau banyak perusahaan disebuah negara. Sze (2004) menjelaskan bahwa seluruh kondisi ekonomi (makro) dapat memengaruhi kinerja pasar properti. Sebagai contoh, perubahan dalam iklim keuangan makro memengaruhi keuntungan perusahaan properti karena perubahan tingkat suku bunga dan tingkat inflasi.
Penurunan nilai modal perusahaan properti dapat menghambat kemampuan perusahaan untuk meminjam dana melalui fasilitas kredit. Hal ini akan mengakibatkan penurunan investasi dan memperlambat pertumbuhan ekonomi (McWilliams, 1992). Fraser (1993) menjelaskan bahwa pasar properti dan ekonomi adalah dua hal yang saling berhubungan. Sebagai contoh, rendahnya tingkat suku bunga pinjaman akan berdampak rendahnya biaya modal dan efeknya adalah peningkatan investasi pada pasar properti. Peningkatan investasi akan berdampak pada kemajuan suatu negara

Shah et al. (2012) menjelaskan bahwa secara nilai tukar memiliki hubungan dan memengaruhi pergerakan nilai saham perusahaan-perusahaan yang menggunakan kegiatan produksinya dengan barang-barang impor. Secara jangka pendek, kurs tidak memiliki hubungan yang signifikan terhadap kegiatan ekonomi perusahaan. Selanjutnya Shah et al. (2012) juga menyatakan pergerakan nilai tukar memengaruhi asset riil perusahaan, terlepas apakah perusahaan tersebut memiliki usaha luar negeri atau tidak.

Tujuan dari penelitian ini adalah menganalisis potensi financial distress PWON dengan menggunakan metode perhitungan Zmijewski. Selanjutnya adalah untuk menganalisis hubungan antara financial distress dengan variabel-variabel independen lainnya.

\section{METODE PENELITIAN}

Untuk menghitung potensi financial distress digunakan metode Zmijewski. Microsoft Excel 2010 digunakan sebagai software pembantu dalam menghitung potensi financial distress. Untuk menghitung korelasi antara variabel dependen dan independen, digunakan software Eviews 6 dengan metode error correction model. Data yang digunakan adalah data kuartal dari kuartal 1 tahun 2006 sampai dengan kuartal 1 tahun 2016. Persamaan Zmijewski dijabarkan sebagai berikut (Kleinert, 2014):

$$
Z=-4,3-4,5 \times 1+5,7 \times 2+0,004 \times 3
$$

Keterangan: x1(Laba Setelah Pajak/Total Aktiva (ROA)); x2 (Total Hutang/Total Aktiva (Debt Ratio)); x3 (Aktiva Lancar/Kewajiban Lancar (Current Ratio)). 


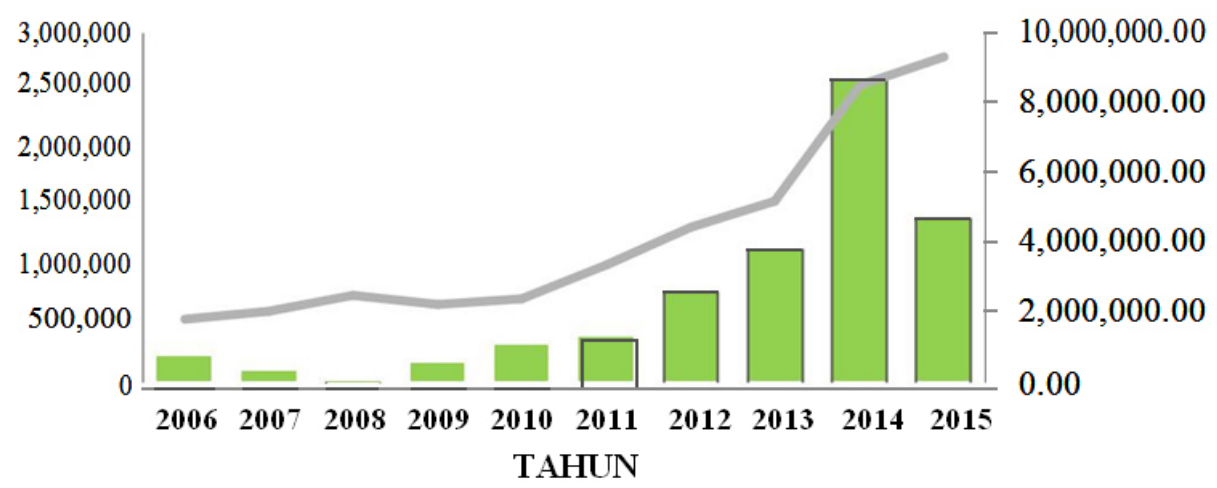

$\square$ Laba setelah pajak

_ Hutang usaha

Gambar 1. Perbandingan laba setelah pajak dan hutang usaha PWON (Laporan Keuangan PWON tahun 20062015 (diolah))

Kriteria penilaian kesehatan kinerja keuangan dengan menggunakan Zmijewski adalah sebagai berikut: Z > 0,5 maka perusahaan dinyatakan potensial mengalami financial distress atau digantikan dengan singkatan POT. Selanjutnya, $\mathrm{S}<0,5$ maka perusahaan dinyatakan sehat dari financial distress atau digantikan dengan singkatan SHT.

Penelitian ini menggunakan teknik analisis data time series dengan alat analisisnya adalah pendekatan kointegrasi dan Error Correction Model (ECM). Perangkat lunak yang digunakan untuk pengolahan data pada penelitian ini adalah E-Views 6.

\section{Uji Kestasioneran Data Deret Waktu}

Juanda dan Junaidi (2012) menjelaskan salah satu asumsi penting dalam pendugaan parameter model regresi dengan metode kuadrat terkecil (least square) adalah error (residual) yang homoskedastisitas, artinya ragam peubah tak bebas (Yt) harus konstan. Asumsi lainnya adalah tidak ada korelasi antar error, yang juga berarti tidak ada korelasi diantara peubah Yt dengan Yt-1 atau Yt yang lain (tidak ada autokorelasi).

Persoalan krusial dalam analisis perilaku deret waktu adalah data sering kali menunjukan kondisi tidak stasioner. Data deret waktu yang tidak stasioner akan bersifat heteroskedastisitas atau memiliki autokorelasi. Selain itu, pada kondisi non-stasioner sering ditemui dua atau lebih peubah deret waktu bergerak dengan arah yang sama atau berlawanan, tetepi pergerakan tersebut terjadi secara kebetulan dan tidak memiliki dasar teori atau logika (Juanda dan Junaidi, 2012). Pengujian untuk mengukur stasioneritas dilakukan dengan menggunakan Augmented Dickey Fuller (ADF) test atau uji akar-akar unit (unit root test).

Hipotesis yang digunakan dalam pengujian ini adalah sebagai berikut: $\mathrm{H} 0=$ data tidak stasioner (mengandung unit root); $\mathrm{H} 1=$ data stasioner (tidak mengandung unit root). Penolakan $\mathrm{H} 0$ menunjukkan data yang dianalisis sudah stasioner. Data dikatakan stasioner jika ADF test statistics lebih kecil dari nilai kritis MacKinnon.

Engle-Granger Cointegration

Menurut Gujarati dan Porter (2012) secara ekonomi, apabila antar variabel memiliki hubungan jangka panjang, serta variabel-variabel yang tidak stasioner dan residual dari kombinasi linear tersebut harus stasioner, sehingga dapat diketahui kemungkinan terjadinya kestabilan jangka panjang antara variabelvariabel yang digunakan. Amalia dan Fahmi (2007) menyatakan bahwa Engle-Granger Cointegration sebetulnya menggunakan metode ADF yang terdiri dari dua tahap. Tahap pertama dilakukan dengan meregresikan persamaan variabel dependen dengan variabel independen kemudian didapatkan residual (Ut) dari persamaan tersebut. Tahapan kedua dilakukan dengan menggunakan ADF test. Jika signifikan maka varibel Ut adalah stasioner. Artinya, variabel yang digunakan tidak stasione. Namun, secara jangka panjang variabel tersebut cenderung menuju keseimbangan. Adapun model yang digunakan dalam penelitian ini adalah sebagai berikut:

$$
\begin{aligned}
\mathrm{Zmi}_{\mathrm{t}}= & \beta_{0}+\beta_{1} \text { kurs }_{\mathrm{t}}+\beta_{2} \mathrm{SB}_{\mathrm{t}}+\beta_{3} \mathrm{GRS}_{\mathrm{t}}+\beta_{4} \mathrm{GREXP}_{\mathrm{t}}+\beta_{5} \mathrm{GRCO} \\
& \mathrm{GS}_{\mathrm{t}}+\beta 6 \mathrm{ER}_{\mathrm{t}}+\mathrm{e}_{\mathrm{t}}
\end{aligned}
$$


Keterangan: Zmit (Nilai Zmijewski pada periode t); $\beta 0$ (intercept); kurst (Nilai kurs pada periode t); SBt (Nilai suku bunga periode t); GRSt (Nilai growth sales periode t); GREXPt (Nilai growth operating expense periode t); GRCOGSt (Nilai growth cost of goods sold periode t); DERt (Nilai debt to equity ratio periode t); et (Error distribunce periode).

\section{Error Correction Model (ECM)}

Model yang memasukan penyesuaian untuk melakukan koreksi ketidakseimbangan jangka pendek menuju keseimbangan jangka panjang disebut Error Correction Model (Juanda dan Junaidi, 2012). Secara umum dapat dikatakan bahwa ECM sering dipandang sebagai salah satu model dinamik yang sangat terkenal dan banyak diterapkan dalam studi empiris karena kemampuan ECM dalam menganalisis fenomena ekonomi jangka pendek dan jangka panjang (Waluyati et al. 2015).

Kelebihan dari ECM adalah seluruh komponen dan informasi pada tingkat variabel telah dimasukan dalam model, mamasukan semua bentuk kesalahan untuk dikoreksi, menghindari terjadinya trend dan regresi semu (spurious regression). Artinya, model ECM mampu memberikan makna lebih luas dari estimasi model ekonomi sebagai pengaruh perubahan variabel independen terhadap dependen dalam hubungan jangka pendek dan jangka panjang (Waluyati et al. 2015).

Hasil Estimasi pengujian akar-akar unit dan kointegrasi dengan menggunakan ECM adalah seperti berikut:

$$
\begin{aligned}
\mathrm{DZmi}_{\mathrm{t}}= & \beta_{0}+\beta_{1} \text { Dkurs }_{\mathrm{t}}+\beta_{2} \mathrm{DSB}_{\mathrm{t}}+\beta_{3} \text { DGRS }_{\mathrm{t}}+\beta_{4} \text { DGREX }_{\mathrm{t}}^{+} \\
& \beta_{5} \text { DGRCOGS }_{\mathrm{t}}+\beta_{6} \text { DDER }_{\mathrm{t}}+\beta_{7} \mathrm{u}_{\mathrm{t}-1}+\mathrm{e}_{\mathrm{t}}
\end{aligned}
$$

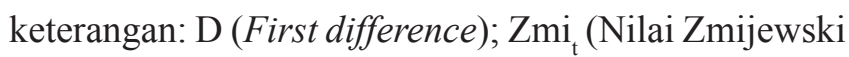

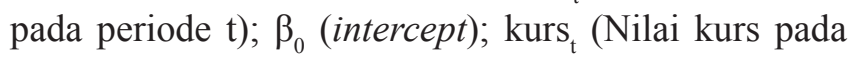
periode $\mathrm{t}$ ); $\mathrm{SB}_{\mathrm{t}}$ (Nilai suku bunga periode $\mathrm{t}$ ); $\mathrm{GRS}_{\mathrm{t}}$ (Nilai growth sales periode t); GREXPt (Nilai growth operating expense periode t); GRCOGSt (Nilai growth cost of goods sold periode t); $\mathrm{DER}_{\mathrm{t}}$ (Nilai debt to equity ratio periode $\mathrm{t}) ; \mathrm{U}_{\mathrm{t}-1}$ (Error correction term periode $\mathrm{t}-1) ; \mathrm{e}_{\mathrm{t}}$ (Error distribunce periode $\left.\mathrm{t}\right)$.

Hipotesis yang digunakan dalam uji signifikansi secara parsial pada variabel independen terhadap variabel dependen dengan tingkat signifikan $90 \%(\alpha=10 \%)$ adalah sebagai berikut:
1. Pengaruh kurs terhadap nilai Zmijewski.

H0 : Kurs tidak berpengaruh secara signifikan terhadap nilai Zmijewski.

H1 : Kurs berpengaruh secara signifikan terhadap nilai Zmijewski.

2. Pengaruh suku bunga pinjaman bank terhadap nilai Zmijewski.

H0 : Sukubunga pinjaman bank tidak berpengaruh secara signifikan terhadap nilai Zmijewski.

H1 : Suku bunga pinjaman bank berpengaruh secara signifikan terhadap nilai Zmijewski.

3. Pengaruh growth operating expense terhadap nilai Zmijewski.

H0 : Growth operating expense tidak berpengaruh secara signifikan terhadap nilai Zmijewski.

H1 : Growth operating expense berpengaruh secara signifikan terhadap nilai Zmijewski.

4. Pengaruh growth sales terhadap nilai Zmijewski

$\mathrm{HO}$ : Growth sales tidak berpengaruh secara signifikan terhadap nilai Zmijewski.

H1 : Growth sales berpengaruh secara signifikan terhadap nilai Zmijewski.

5. Pengaruh growth COGS terhadap nilai Zmijewski

H0 : Growth COGS tidak berpengaruh secara signifikan terhadap nilai Zmijewski.

H1 : Growth COGS berpengaruh secara signifikan terhadap nilai Zmijewski.

6. Pengaruh DER terhadap nilai Zmijewski

H0 : DER tidak berpengaruh secara signifikan terhadap nilai Zmijewski.

H1 : DER berpengaruh secara signifikan terhadap nilai Zmijewski.

\section{HASIL}

Faktor makro ekonomi dan mikro ekonomi dapat menjadi penyebab sebuah perusahaan mengalami financial distress Faktor makro ekonomi yang digunakan dalam penelitian ini antara lain tingkat suku bunga pinjaman bank dan nilai tukar mata uang asing (kurs). Sedangkan, faktor mikro ekonomi antara lain pertumbuhan nilai penjualan, pertumbuhan beban operasi, pertumbuhan harga pokok produksi (COGS) dan rasio hutang terhadap ekuitas (DER). 


\section{Nilai Tukar}

Shah et al. (2012) menjelaskan bahwa secara nilai tukar memiliki hubungan dan memengaruhi pergerakan nilai saham perusahaan-perusahaan yang menggunakan kegiatan produksinya dengan barang-barang impor. Secara jangka pendek, kurs tidak memiliki hubungan yang signifikan terhadap kegiatan ekonomi perusahaan.

Peningkatan nilai tukar Rupiah terhadap US dollar pada tahun 2008 yang disebabkan oleh krisis finansial global yang bedampak pada hampir seluruh negara di dunia. Pada tahun yang sama pula, penguatan nilai tukar Rupiah terhadap US dollar. Hal ini disebabkan oleh pengalihan aset investor asing dari aset yang dinilai berisiko tinggi kepada aset yang lebih aman.

Selain itu, pada pertengahan tahun 2008, Amerika Serikat melakukan quantitative easing (QE) yang sedikit banyak membantu kegiatan perekonomian negara tersebut. Quantitative easing adalah pembelian aset oleh The Fed (Bank Sentral Amerika Serikat) yang bertujuan untuk mengeluarkan perekonomian Amerika dari krisis Moneter karena krisis subprime mortgage. Banyaknya dana yang dikeluarkan The Fed ikut meningkatkan pasar keuangan negara-negara berkembang, salah satunya Indonesia.

\section{Suku Bunga Pinjaman Bank Indonesia}

Suku bunga pinjaman bank mengalami fluktuasi yang amat beragam dan cenderung stabil selama periode 2009 kuartal 4 sampai dengan 2013 kuartal 4. Suku bunga pinjaman tertinggi adalah selama tahun 2008 kuartal satu sampai dengan 2009 kuartal 3, yaitu menyentuh berada di kisaran 13,2\% sampai dengan $14,4 \%$. Dimana saat itu Indonesia masih mengalami efek krisis moneter berkepanjangan.

Ketika suku bunga naik maka akan berdampak pada kredit properti yang berbunga akan meningkat. Apabila ditambah dengan kondisi daya beli masyarakat yang menurun, maka akan berdampak kepada peningkatan nilai kredit macet di masyarakat. Peningkatan kredit macet tersebut akan menghambat aliran dana masuk ke perusahaan properti itu sendiri.

\section{Growth Operating Expense}

Beban operasi adalah salah satu kategori pengeluaran dari bisnis utama sebuah perusahaan. Salah satu tantangan dari sebuah perusahaan adalah membuat beban operasi rendah tanpa mengurangi kemampuan perusahaan untuk bersaing dengan para kompetitor. Growth operating expense PWON mengalami peningkatan yang tajam. Operating expense pada kuartal 3 tahun 2011 bila dibandingkan dengan kuartal 3 tahun 2010, nilainya meningkat $263 \%$. Ada tiga hal yang menyebabkan operating expense PWON meningkat tajam, yaitu meningkatnya senior secured note, meningkatnya hutang bank dan meningkatnya utang obligasi.

\section{Growth Sales}

Opler dan Titman (1994) melakukan penelitian menggunakan market share dan pertumbuhan penjualan sebagai proksi kinerja perusahaan, menemukan bahwa hubungan antara kinerja perusahaan dan financial distress adalah negatif dan signifikan.

Perkembangan penjualan PWON terbilang cukup fluktuatif. Ditandai dengan meningkatnya angka penjualan pada kuartal 1 tahun 2010 yang mencapai $179 \%$ bila dibandingkan dengan penjualan pada kuartal 1 tahun 2009. Hal tersebut disebabkan oleh pada tahun 2010, PWON berhasil mencatatkan angka penjualan atas apartment dan kantor sebesar Rp144.112 (dalam jutaan Rupiah). Angka tersebut didapat setelah PWON melakukan ekspansi properti dari hanya Surabaya menjadi ditambah Jakarta. Model ekspansi yang dilakukan adalah dengan membangun superblock Gandaria City di kawasan Jakarta Selatan.

\section{Growth Cost of Goods Sold}

Beban pokok penjualan (Cost of Goods Sold/COGS) terbesar PWON terdapat pada kuartal 1 tahun 2010 dibandingkan dengan kuartal 1 tahun 2009 (quarter to quarter). Hal tersebut terjadi karena pada kuartal 1 tahun 2010 terdapat beban pokok penjualan tanah dan bangunan serta apartmen dan perkantoran. PWON mencatatkan penjualan yang tinggi pada periode yang sama dengan meningkatnya beban pokok penjualan, karena ekspansi proyek pada tahun tersebut ke Jakarta. 


\section{Debt to Equity Ratio}

Jandik dan Makhija (2005) melakukan penelitan mengenai efek hutang (debt) dan struktur hutang pada kinerja perusahan dan menemukan bahwa hubungan antara kinerja perusahaan dan leverage adalah negatif. Asquith et al. (1994) menyatakan bahwa leverage perusahaanmerupakan faktoryang paling kuatpenyebab financial distress. Leverage yang tinggi merupakan penyebab utama kurangnya kas perusahaan.

Debt to Equity Ratio (DER) adalah rasio yang membandingkan antara nilai hutang, baik itu hutang jangka panjang maupun jangka pendek terhadap nilai ekuitas perusahaan. Perusahaan yang memiliki nilai DER dibawah satu mengindikasikan perusahaan memiliki hutang yang lebih kecil daripada ekuitas. Secara nilai rasio DER, PWON memiliki DER yang baik. Trend DER PWON Periode Q1 2006-Q1 2016 menunjukan hasil yang selalu diatas satu (Gambar 2). Indikasi ini menggambarkan bahwa PWON sudah mampu mengelola hutang dengan ekuitasnya dengan baik.

\section{Potensi Financial Distress PWON}

Husein dan Pambekti (2014) menjelaskan bahwa tingkat akurasi Zmijewski lebih tinggi daripada metode lain karena dua dari tiga variabel yang terdapat dalam perhitungan adalah variabel leverage. Sebuah perusahaan yang memiliki tingkat hutang yang tinggi maka lebih besar memiliki kemungkinan untuk mengalami kesulitan keuangan.

Perhitungan Zmijewski menitikberatkan perhitungan dengan rasio kelompok rate of return, liquidity, leverage, turnover, fixed payment coverage, trends, firm size, dan stock return volatility (Yuliastary dan Wirakusuma, 2014). Kriteria penilaiannya adalah apabila $\mathrm{Z}<0,5$ maka perusahaan dinyatakan sehat.

Hasil penghitungan Periode Q1 2006- Q1 2016, PWON berada dalam kategori perusahaan sehat (Gambar 2). Titik potong dengan metode ini adalah 0,5 maka dapat dinyatakan bahwa dalam apabila nilai $\mathrm{X}$ berada jauh dibawah 0,5 maka perusahaan dinyatakan lebih sehat. Nilai $Z$ terbesar PWON didapat pada kuartal 4 tahun $2014(Z=-2,11)$ dan nilai terkecil atau yang paling mendekati 0,5 adalah kuartal 1 tahun $2006(Z=0,02)$.

Salah satu variabel penghitungan metode Zmijewski adalah Return on Asset (ROA). Semakin tinggi nilai ROA, maka semakin baik pula kemampuan perusahaan dalam mengelola asetnya. Nilai ROA PWON sangat kecil dan mengindikasikan bahwa PWON belum maksimal dalam mengelola asetnya. Tercatat ROA terbesar PWON adalah pada kuartal 4 tahun 2014 sebesar $15,5 \%$. Artinya, PWON hanya menggunakan $15,5 \%$ dari total asetnya untuk mendapatkan laba bersih.

Variabel kedua pembentuk metode Zmijewski adalah Debt Ratio. Secara umum debt ratio PWON yang kecil menggambarkan pengelolaan hutang terhadap aset sudah baik. Nilai debt ratio PWON selalu berada dibawah 1 dengan nilai paling besar adalah pada kuartal 1 tahun 2006 sebesar 81,2\%.

Variabel terakhir pembentuk metode Zmijewski adalah rasio lancar atau currentratio. Nilai currentratio PWON selama periode pengamatan berfluktuatif. Secara umum nilai current ratio diatas 1 menggambarkan bahwa perusahaan dapat mengembalikan hutang lancar dengan menggunakan aset lancar.

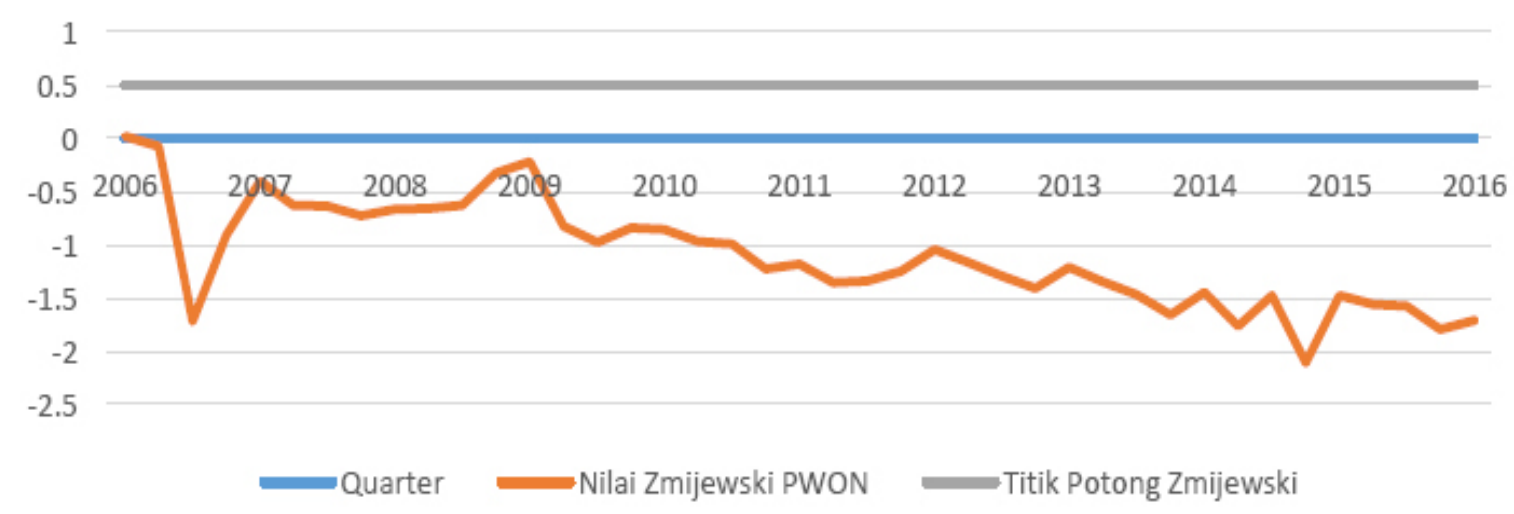

Gambar 2. Nilai Zmijewski PWON Periode Q1 2006 - Q1 2016 


\section{Hasil Uji Kestasioneran Data Deret Waktu}

Zmijewski, kurs dan suku bunga tidak stasioner pada level karena nilai mutlak ADF variabel tersebut lebih kecil dari nilai mutlak Mc Kinnon. Sedangkan untuk variabel DER, growth COGS, growth operating expense dan growth sales telah stasioner pada level. Oleh karena data untuk tiga variabel lainnya tidak stasioner maka perlu dilanjutkan pada uji akar unit pada first difference. Hasil pengujian akar unit pada Level pada Tabel 2.

\section{Hasil Uji Augmented Dickey Fuller (ADF)}

Hasil uji stasionaritas data pada first difference menunjukkan bahwa ketujuh variabel yang digunakan dalam penelitian telah stasioner pada tingkat first difference. Hal ini dikarenakan nilai mutlak ADF lebih besar dari nilai mutlak Mc Kinnon Critical Values. Hasil Pengujian Akar Unit pada First Difference di Tabel 3.

\section{Uji Kointegrasi Zmijewski}

Nilai ADF t-statistic lebih kecil daripada nilai kritis MacKinnon pada taraf nyata $5 \%$, maupun $10 \%$ sehingga residual persamaan regresi stasioner pada tingkat level. Hal ini mengindikasikan terdapat hubungan kointegrasi diantara variabel yang digunakan, sehingga selanjutnya dapat dilakukan pengestimasian Engle-Granger Cointegration untuk mengidentifikasi hubungan jangka pendek menuju keseimbangan jangka panjang. Hasil Uji Kointegrasi Zmijewski pada Tabel 4.

Model persamaan Zmijewski terhadap variabel independen dalam jangka panjang adalah sebagai berikut:

$$
\begin{aligned}
\mathrm{Y}= & -0,643 \text { Kurs }^{*}+ & 0,06 \mathrm{SB}^{*}-0,001 \mathrm{GRS} & + \\
& 0,0003 \text { GREXP }^{*} & - & 0,001 \mathrm{GRCOGS} * \\
& 0,705 \text { DER }^{*} & &
\end{aligned}
$$

Variabel kurs memiliki koefisien -0,643. Variabel suku bunga memiliki koefisien 0,06. Growth operating expense memiliki koefisien 0,0003. Growth COGS memiliki koefisien -0,001. Debt to equity ratio memiliki koefisien 0,705 . Ke lima variabel tersebut memiliki signifikansi pada taraf $1 \%$. Sedangkan, variabel pertumbuhan penjualan tidak memiliki signifikansi terhadap model jangka panjang Zmijewski.

Tabel 2. Hasil pengujian akar unit pada level

\begin{tabular}{lccccc}
\hline \multirow{2}{*}{ Variabel } & \multirow{2}{*}{ Nilai ADF } & \multicolumn{3}{c}{ Nilai Kritis Mc Kinnon } & \multirow{2}{*}{ Keterangan } \\
\cline { 3 - 5 } & & 1\% level & $5 \%$ level & $10 \%$ level & \\
\hline DER & -4.848 & -3.606 & -2.937 & -2.607 & stasioner \\
GRCOGS & -4.576 & -3.606 & -2.937 & -2.607 & stasioner \\
GREXP & -2.901 & -3.606 & -2.937 & -2.607 & stasioner \\
GRS & -3.629 & -3.606 & -2.937 & -2.607 & stasioner \\
ZMIJEWSKI & -2.580 & -3.610 & -2.939 & -2.608 & tidak stasioner \\
KURS & -0.459 & -3.606 & -2.937 & -2.607 & tidak stasioner \\
SB & -2.197 & -3.610 & -2.939 & -2.608 & tidak stasioner \\
\hline
\end{tabular}

Sumber: Laporan Keuangan PWON dan Data Bank Indonesia Q1 Tahun 2006-Q1 Tahun 2016

Tabel 3. Hasil pengujian akar unit pada first difference

\begin{tabular}{lccccc}
\hline \multirow{2}{*}{ Variabel } & \multirow{2}{*}{ Nilai ADF } & \multicolumn{3}{c}{ Nilai Kritis Mc Kinnon } & \multirow{2}{*}{ Keterangan } \\
\cline { 3 - 5 } & & $1 \%$ level & $5 \%$ level & $10 \%$ level & \\
\hline DER & -5.418 & -3.670 & -2.964 & -2.621 & stasioner \\
GRCOGS & -10.656 & -3.610 & -2.939 & -2.608 & stasioner \\
GREXP & -7.344 & -3.610 & -2.939 & -2.608 & stasioner \\
GRS & -6.908 & -3.616 & -2.941 & -2.609 & stasioner \\
ZMIJEWSKI & -8.440 & -3.610 & -2.939 & -2.608 & stasioner \\
KURS & -5.077 & -3.610 & -2.939 & -2.608 & stasioner \\
SB & -5.261 & -3.610 & -2.939 & -2.608 & stasioner \\
\hline
\end{tabular}

Sumber: Laporan Keuangan PWON dan Data Bank Indonesia Q1 Tahun 2006-Q1 Tahun 2016 (diolah) 
Tabel 4. Hasil uji kointegrasi zmijewski

\begin{tabular}{llll}
\hline & & t-Statistic & Prob. $^{*}$ \\
\hline $\begin{array}{l}\text { Augmented Dickey-Fuller test } \\
\text { statistic }\end{array}$ & -4.559402 & 0.0007 \\
Test critical values: & $1 \%$ level & -3.605593 & \\
& $5 \%$ level & -2.936942 & \\
& $10 \%$ level & -2.606857 & \\
\hline
\end{tabular}

Persamaan Zmijewski terhadap variabel independen dalam jangka pendek adalah sebagai berikut:

$$
\begin{aligned}
\mathrm{D}(\mathrm{Y})= & -0,941 \mathrm{D}\left(\mathrm{Kurs}_{\mathrm{t}}\right) *+0,101 \mathrm{D}\left(\mathrm{SB}_{\mathrm{t}}\right) *{ }_{-} \\
& 0,0006 \mathrm{D}\left(\mathrm{GRS}_{\mathrm{t}}\right) *+0,0004 \mathrm{D}\left(\mathrm{GREXP}_{\mathrm{t}}\right){ }_{-} \\
& 0,001 \mathrm{D}\left(\mathrm{GRCOGS}_{\mathrm{t}}\right) *+0,651 \mathrm{D}\left(\mathrm{DER}_{\mathrm{t}}\right) *- \\
& 0,0897 \mathrm{UT} 3(\mathrm{t}-1)^{*}
\end{aligned}
$$

Variabel D (kurs) memiliki koefisien -0,941. Variabel D (suku bunga) memiliki koefisien 0,101. D (Growth COGS) memiliki koefisien 0,001. D (Debt to equity ratio) memiliki koefisien 0,65. Empat variabel tersebut signifikan pada taraf 1\%. Sedangkan D (Growth operating expense) dan $\mathrm{D}$ (growth sales) yang masingmasing memiliki koefisien 0,0004 dan -0,0006 memiliki signifikansi pada taraf $10 \%$.

\section{Hubungan Antara Kurs dengan Zmijewski}

Hasil model jangka panjang pada Tabel 5 menunjukan variabel kurs memiliki probabilitas $0,000<0,1$ maka tolak $\mathrm{H} 0$ artinya variabel kurs berpengaruh signifikan terhadap nilai Zmijewski pada taraf nyata $10 \%$. Sedangkan dalam model jangka pendek menunjukan variabel kurs memiliki probabilitas $0,000<0,1$ maka tolak H0 artinya variabel kurs berpengaruh signifikan terhadap nilai Zmijewski pada taraf nyata $10 \%$.

Secara hubungan jangka panjang apabila nilai kurs rupiah terhadap dollar Amerika menguat sebesar 1\%, maka nilai Zmijewski akan menurun sebesar 0,643\%. Penurunan ini akan berdampak nilai Zmijewski akan menjauhi nilai kritisnya, yaitu 0,5 . Secara jangka pendek pun apabila kurs menguat $1 \%$ maka nilia Zmijewski akan menurun sebesar 0,941\%.

Penguatan atau pelemahan mata uang asing dapat menyebabkan biaya produksi dan biaya kewajiban dalam mata uang asing menjadi tinggi (Baillie dan McMahon, 1990). Dengan meningkatnya biaya produksi dan kewajiban, akan mengakibatkan penurunan daya saing perusahaan dan akan berujung kepada potensi financial distress (Budilaksono, 2014).
Variabel penyusun metode Zmijewski lebih mengarah kepada analisis balance sheet. Penguatan nilai tukar mata uang asing akan memengaruhi total hutang perusahaan yang mengakibatkan tingginya nilai hutang dan akan berdampak kepada tingginya nilai Zmijewski. Namun, secara jangka panjang valuta asing atau kurs akan memengaruhi tingkat suku bunga. Suku bunga akan secara terus menerus diintervensi pemerintah untuk mempertahankan nilai. Shah et al. (2012) juga menyatakan pergerakan nilai tukar memengaruhi asset riil perusahaan, terlepas apakah perusahaan tersebut memiliki usaha luar negeri atau tidak

\section{Hubungan Antara Suku Bunga Pinjaman Dengan Zmijewski}

Hasil model jangka panjang pada Tabel 5 menunjukan variabel suku bunga memiliki probabilitas $0,000<0,1$ maka tolak $\mathrm{H} 0$ artinya variabel suku bunga berpengaruh signifikan terhadap nilai Zmijewski pada taraf nyata $10 \%$. Sedangkan dalam model jangka pendek menunjukan variabel suku bunga memiliki probabilitas $0,000<0,1$ maka tolak H0 artinya variabel suku bunga berpengaruh signifikan terhadap nilai Zmijewski pada taraf nyata $10 \%$.

Secara hubungan jangka panjang apabila nilai suku bunga pinjaman menguat sebesar $1 \%$, maka nilai Zmijewski akan meningkat sebesar 0,061\%. Peningkatan ini akan berdampak nilai Zmijewski akan mendekati nilai kritisnya, yaitu 0,5 . Secara jangka pendek pun apabila suku bunga pinjaman menguat $1 \%$, maka nilai Zmijewski akan meningkat sebesar $0,101 \%$.

Novianto dan Iramani (2015) menjelaskan bahwa suku bunga adalah salah satu faktor eksternal yang memengaruhi nilai perusahaan. Semakin tingi tingkat suku bunga maka nilai perusahaan akan menurun bagi para investor dengan indikasi bahwa konsumen akan memilih untuk tidak melakukan tindakan konsumsi khususnya di pasar properti dan real estate. Dengan menurunnya konsumsi maka akan berdampak kepada profitabilitas perusahaan.

\section{Hubungan Antara Pertumbuhan Penjualan Dengan Zmijewski}

Hasil model jangka panjang pada Tabel 5 menunjukan variabel pertumbuhan penjualan memiliki probabilitas $0,474>0,1$ makaterima $\mathrm{H} 0$ artinya variabel pertumbuhan 
penjualan tidak berpengaruh signifikan terhadap nilai Zmijewski pada taraf nyata $10 \%$. Sedangkan dalam model jangka pendek menunjukan variabel pertumbuhan penjualan memiliki probabilitas 0,077 $<0,1$ maka tolak H0. Artinya, variabel pertumbuhan penjualan berpengaruh signifikan terhadap nilai Zmijewski pada taraf nyata $10 \%$.

Secara hubungan jangka panjang pertumbuhan penjualan tidak berpengaruh signifikan terhadap nilai Zmijewski. Namun, secara jangka pendek pun apabila pertumbuhan penjualan menguat $1 \%$ maka nilai Zmijewski akan meningkat sebesar $0,001 \%$. Penurunan ini akan berdampak nilai Zmijewski akan menjauhi nilai kritisnya, yaitu 0,5 .

Penyebab umum terjadinya kebangkrutan pada perusahaan adalah turunnya tingkat penjualan. Penurunan penjualan itu sendiri bisa menyebabkan terjadinya penurunan pendapatan perusahaan akan berdampak pada turunnya laba. Apabila perusahaan tidak mampu mendeteksi hal tersebut maka perusahaan akan mengalami kebangkrutan (Budilaksono, 2014).

Opler dan Titman (1994) melakukan penelitian menggunakan market share dan pertumbuhan penjualan sebagai proksi kinerja perusahaan, menemukan bahwa hubungan antara kinerja perusahaan dan financial distress adalah negatif dan signifikan.

\section{Hubungan Antara Growth Operating Expense Dengan Zmijewski}

Hasil model jangka panjang pada Tabel 5 menunjukan variabel growthoperating expense memiliki probabilitas $0,000<0,1$ maka terima H0. Artinya, variabel growth operating expense berpengaruh signifikan terhadap nilai Zmijewski pada taraf nyata $10 \%$. Sedangkan dalam model jangka pendek menunjukan variabel growth operating expense memiliki probabilitas $0,084<0,1$ maka tolak H0. Artinya, variabel growth operating expense berpengaruh signifikan terhadap nilai Zmijewski pada taraf nyata $10 \%$.

Secara hubungan jangka panjang apabila nilai growth operating expense menguat sebesar $1 \%$ maka nilai Zmijewski akan meningkat sebesar $0,0002 \%$. Peningkatan ini akan berdampak nilai Zmijewski akan mendekati nilai kritisnya, yaitu 0,5 . Secara jangka pendek pun apabila growth operating expense menguat 1\% maka nilai Zmijewski akan meningkat sebesar
0,0004\%. Marcus dan Innace (2001) menyatakan bahwa ketika arus kas mengalami penurunan maka kegiatan bisnis perusahaan akan menguras modal kerja sehingga membuat pembayaran upah, pembelian bahan baku dan pembayaran beban operasi akan menjadi sulit.

\section{Hubungan Growth Cost of Goods Sold Dengan Zmijewski}

Hasil model jangka panjang pada Tabel 5 menunjukan variabel cost goods sold memiliki probabilitas 0,000 $<0,1$ maka terima H0. Artinya, variabel cost goods sold berpengaruh signifikan terhadap nilai Zmijewski pada taraf nyata $10 \%$. Sedangkan dalam model jangka pendek menunjukan variabel cost goods sold memiliki probabilitas $0,000<0,1$ maka tolak H0. Artinya, variabel cost goods sold berpengaruh signifikan terhadap nilai Zmijewski pada taraf nyata $10 \%$.

Korelasi nilai growth cost of goods sold adalah negatif dalam model jangka panjang maupun jangka pendek. Jika nilai growth cost of goods sold menguat sebesar $1 \%$ maka nilai Zmijewski akan menurun sebesar $0,001 \%$. Secara jangka pendek pun apabila suku bunga pinjaman menguat $1 \%$ maka nilai Zmijewski akan menurun sebesar $0,001 \%$.

Salah satu variabel metode Zmijewski adalah laba bersih setelah pajak. Rumus perhitungan laba bersih setelah pajak adalah penjualan bersih ditambah pendapatan dikurangi harga pokok penjualan dikurangi bebanbeban pajak. Berarti secara tidak langsung harga pokok penjualan atau cost of goods sold pasti memengaruhi nilai zmijewski, baik secara jangka panjang ataupun jangka pendek.

Dalam perhitungan dengan metode Zmijewski, laba bersih setelah pajak dibandingkan dengan total aktiva atau yang biasa disebut dengan return on asset (ROA). Penelitan Arini (2010) menunjukan bahwa variabel profitabilitas, yang diwakili oleh ROA, berpengaruh signifikan terhadap prediksi financial distress. Semakin besar nilai profitabilitas (ROA) maka akan semakin mengurangi kemungkinan perusahaan mengalami financial distress. Hal tersebut dialami pada kondisi perekonomian sedang stabil. Sedangkan penelitian Andreev (2006) menunjukan bahwa semakin tinggi ROA maka akan meningkatkan potensi perusahaan mengalami financial distress. Hal ini terjadi pada saat perekonomian sedang labil. 


\section{Hubungan Debt to Equity Ratio Dengan Zmijewski}

Hasil model jangka panjang pada Tabel 5 menunjukan variabel debt to equity ratio memiliki probabilitas 0,000 $<0,1$ maka terima H0. Artinya, variabel debt to equity ratio berpengaruh signifikan terhadap nilai Zmijewski pada taraf nyata $10 \%$. Sedangkan dalam model jangka pendek menunjukan variabel debt to equity ratio memiliki probabilitas $0,000<0,1$ maka tolak $\mathrm{H}$. Artinya, variabel debt to equity ratio berpengaruh signifikan terhadap nilai Zmijewski pada taraf nyata $10 \%$.

Korelasi DER dengan Zmijewski dalam model jangka panjang pada PWON bersifat positif. Artinya, apabila nilai DER turun 1 satuan maka nilai Zmijewski akan menurun sebesar 0,705\%. Sedangkan untuk model jangka pendek, apabila nilai DER turun 1 satuan maka nilai Zmijewski akan turun sebesar 0,0651\%.

Nilai DER yang mendekati satu, berarti bahwa ekuitas perusahaan tidak mampu menjamin nilai hutangnya. Tahap selanjutnya adalah ketidakmampuan perusahaan dalam membayar hutang yang berujung kepada kebangkrutan. Hal tersebut berkorelasi dengan nilai Zmijewski. Apabila nilai Zmijewski meningkat, maka perusahaan berpotensi mengalami kebangkrutan.

Jandik dan Makhija (2005) melakukan penelitan mengenai efek hutang (debt) dan struktur hutang pada kinerja perusahan dan menemukan bahwa hubungan antara kinerja perusahaan dan leverage adalah negatif. Asquith et al. (1994) menyatakan bahwa leverage perusahaan merupakan faktor yang paling kuat penyebab financial distress. Leverage yang tinggi merupakan penyebab utama kurangnya kas perusahaan.

\section{Implikasi Manajerial}

Salah satu penyebab turunnya nilai Moody PWON pada tahun 2009 adalah struktur modal dan risiko keuangan. Hal-hal yang perlu dilakukan oleh PWON untuk memperbaiki struktur modal adalah meningkatkan kinerja perusahaan dalam menghasilkan modal kerja dari seluruh aset yang dimiliki oleh perusahaan. Nilai hutang yang cukup tinggi dibandingkan dengan nilai aset, dapat menyebabkan arus kas perusahaan menjadi negatif sehingga akan menyebabkan perusahaan kekurangan aktiva lancar untuk membayar hutang lancar. PWON juga harus mulai meningkatkan kinerja aset yang dimiliki sehingga rasio laba ditahan terhadap total aset tidak terlalu tinggi. Nilai aset turnover PWON juga belum maksimal, meskipun bila dibandingkan dengan kinerja aset perusahaan sejenis, PWON sudah lebih baik. Hal tersebut dapat dapat mengindikasikan bahwa kinerja aset PWON masih tidak terlalu baik. Pendayagunaan aset PWON harus lebih dimaksimalkan. Nilai aset PWON yang besar belum mampu memberikan kinerja keuangan yang baik berdasarkan rasio-rasio keuangan yang digunakan dalam penelitian. Pemanfaatan aset PWON dapat dilakukan dengan menjual sebagian aset sebagai modal usaha pembangunan produk-produk usaha yang lebih menghasilkan. Hutang lancar perusahaan juga dapat ditutupi oleh nilai aktiva lancar yang besar. Hal tersebut dapat dilihat dari nilai current ratio PWON yang selalu berada diatas satu.

Pihak penanam modal atau investor sebagai salah satu faktor keuangan dalam PWON harus memperhatikan rasio-rasio keuangan yang ada. Meskipun demikian, rasio keuangan hanya gambaran kecil dari aktivitas sebuah perusahaan. Namun, mampu merepresentasikan kegiatan keuangan perusahaan. Nilai saham PWON yang masih dibawah para pesaingnya dapat mengindikasikan adanya kinerja keuangan yang tidak baik. Investor harus memperhatikan tingkat hutang PWON yang besar sehingga berakibat kepada risiko keuangan yang tinggi. Salah satu penyebab risiko keuangan yang tinggi adalah penggunaan hutang yang tinggi.

Pemerintah sebagai pengambil kebijakan atau regulator dalam bidang makro ekonomi harus mampu menjaga stabilitas ekonomi. Terbukti bahwa kurs dan tingkat suku bunga mempengaruhi secara signifikan nilai Zmijewski, baik itu secara jangka panjang maupun jangka pendeknya.

Pemerintah harus mampu menjaga stabilitas nilai tukar mata uang. Secara jangka panjang, untuk menstabilkan nilai tukar dapat dilakukan dengan cara menggerakan roda industri dalam negeri. Ketergantungan dengan barang-barang impor dapat menyebabkan ketidakseimbangan neraca perdagangan dan sangat rentan terkena dampak krisis negara lain. Cara tercepat untuk menstabilkan nilai kurs adalah dengan cara membatasi penggunaan mata uang asing untuk transaksi di dalam negeri. Tingkat suku bunga juga 
perlu diperhatikan oleh pemerintah pusat. Perubahan tingkat suku bunga dapat memengaruhi suku bunga kredit dan suku bunga deposito. Bila terlihat ekonomi sedang lesu maka pemerintah perlu menurunkan tingkat suku bunga. Penurunan nilai suku bunga akan membuat permintaan kredit dari perusahaan akan melakukan investasi. Penurunan tingkat suku bunga juga akan berdampak pada penurunan biaya modal perusahaan untuk investasi. Namun, apabila terjadi inflasi maka pemerintah harus menaikan tingkat suku bunga. Gunanya adalah untuk memperlambat aktivitas ekonomi sehingga mengurangi tekanan inflasi.

\section{KESIMPULAN DAN SARAN}

\section{Kesimpulan}

Nilai ROA PWON mengalami penurunan dari tahun 2014 sampai dengan kuartal 1 tahun 2016. Penurunan tersebut dikarenakan oleh beban keuangan PWON meningkat sehingga mengakibatkan penurunan yang signifikan pada laba. Debt ratio PWON selalu berada dibawah 1. Hal tersebut mengindikasikan bahwa pengelolaan hutang terhadap aktiva PWON sudah cukup baik. Nilai current ratio PWON selalu berada diatas 1 yang mengindikasikan bahwa aktiva lancar PWON selalu lebih tinggi dibandingkan dengan kewajiban lancarnya. Penelitian ini menggunakan metode Zmijewski dalam penghitungan potensi kebangkrutan. Nilai Zmijewski PWON selalu berada dalam kondisi sehat. Perbedaan tersebut terjadi karena variabel pembentuk Zmijewski lebih menitikberatkan perhitungan dengan rasio kelompok rate of return, liquidity, leverage, turnover, fixed payment coverage, trends, firm size dan stock return volatility.

Korelasi antara nilai Zmijewski dengan variabel ekonomi makro pada penelitian ini, yaitu nilai tukar mata uang asing dan suku bunga bank Indonesia saling mempengaruhi secara signifikan, baik jangka panjang ataupun jangka pendek. Hal tersebut karena variabel penyusun Zmijewski lebih mengarah kepada analisis balance sheet. Sehingga penguatan nilai tukar mata uang asing akan mempengaruhi nilai total hutang perusahaan. Sedangkan suku bunga berpengaruh kepada kemampuan konsumen dalam mengkonsumsi atau menyimpan dananya yang akan berdampak kepada profitabilitaas perusahaan. Korelasi variabel mikro ekonomi, seperti pertumbuhan beban operasi, pertumbuhan COGS dan DER berpengaruh signifikan terhadap nilai jangka panjang dan jangka pendek Zmijewski. Sedangkan variabel pertumbuhan penjualan hanya berdampak kepada nilai jangka panjang Zmijewski.

\section{Saran}

Menambahkan variabel yang digunakan dalam penelitian. Variabel yang digunakan pada penelitian ini adalah campuran antara makro ekonomi dan mikro ekonomi. Variabel makro ekonomi yang digunakan adalah kurs dan suku bunga pinjaman. Variabel mikro ekonomi yang digunakan adalah growth operating expense, growth net profit, growth COGS dan DER.Apabila menggunakan variabel yang sama, maka objek penelitian dapat diganti. Objek penelitian yang digunakan dalam penelitian ini hanya PWON, disarankan pada penelitian selanjutnya dapat menggunakan objek penelitian lain atau menambahkan objek menjadi lebih dari satu perusahaan dalam subsektor industri yang sama.

Penelitian ini menggunakan error correction model sebagai estimasi untuk mencari korelasi antara variabel dependen dan independen. Disarankan pada penelitian selanjutnya diharapkan menggunakan metode selain error correction model. Apabila data yang didapat adalah deret waktu maka penelitian selanjutnya dapat menggunakan Vector Error Correction Model atau Vector Autoregression.

\section{DAFTAR PUSTAKA}

Amalia S, Fahmi I. 2007. Faktor-faktor yang memengaruhi impor susu Indonesia. Jurnal Manajemen dan Agribisnis 4(2):91-102.

Andreev YA. 2006. Predicting Financial Distress Og Spanish Companies, Autonomous University of Barcelona. Spain: Department of Business Economics Bellaterra.

Arini D. 2010. rasio keuangan untuk memprediksi kondisi financial distress perusahaan manufaktur yang terdaftar di bursa efek Jakarta [tesis]. Surakarta: Universitas Muhammadiyah Surakarta.

Baillie R, Mcmahon P. 1989. The Foreign Exchange Market: Theory and Econometrics Evidence. Cambridge: Cambridge University Press.

Budilaksono A. 2014. Faktor-faktor yang memengaruhi financialdistress(kesulitankeuangan)perusahaan (tinjauan atas perusahaan non keuangan di bursa 
efek Indonesia). Jurnal Informasi Keuangan Dan Akuntasi 12(2): 87-102.

Dwijayanti PF. 2010. Penyebab,dampak dan prediksi dari financial distress serta solusi untuk mengatasi financial distress. Jurnal Akuntansi Kontemporer 2(2): 191-205.

Fraser WD. 1993. Principles of Property Investment and Pricing. Ed. ke-2. London: The Macmilland Press Ltd. https://doi.org/10.1007/978-1-34913311-6.

Gujarati DN, Porter DC. 2012. Dasar-dasar Ekonometrika. Penerjemah: Raden Carlos Mangunsong.Jakarta: Erlangga.

Haryetti. 2010. Analisis financial distress untuk memprediksi risiko kebangkrutan perusahaan (studi kasus pada industri perbankan di Bei). Jurnal Manajemen Fakultas Ekonomi Unri 18(2):24.

Husein M, Fakhri, Pambekti GT. 2014. Precision of the models of altman, springate, zmijewski, and grover for predicting the financial distress. Journal of Economics, Business, And Accountancy Ventura 17(3): 405-416. https:// doi.org/10.14414/jebav.v17i3.362.

Jandik T, Makhija AK. 2005. Debt structure and corporate performance after unsuccessful takeovers: evidence from targets that remain independent. Journal of Corp Finan 11: 882-914. https://doi.org/10.1016/j.jcorpfin.2004.04.002.

Juanda B, Junaidi. 2012. Ekonometrika Deret Waktu Teori dan Aplikasi. Bogor: PT Penerbit IPB Press.

Kleinert MK. 2014. Comparison of accountingbased bankruptcy prediction models of Altman (1968), Ohlson (1980), And Zmijewski (1984) To German and Belgian Listed Companies During 2008-2013 [tesis]. Twente: University of Twente.

Marcus PF, Innace JJ. 2001. Cash Flow Crisis. Painewebber World Steel Dynamics.

Mcwilliams D. 1992. Commercial property and company borrowing. London: The Royal Institution Of Chartered Surveyors. Research Paper No. 22.

Novianto A, Iramani R. 2015. Pengaruh keputusan keuangan, struktur kepemilikan dan tingkat suku bunga terhadap nilai perusahaan property dan real estate yang go public. Journal of Business and Banking 5(1):65-82. https://doi.org/10.14414/ jbb.v5i1.473

Opler T, Tiltman S. 1994. Financial distress and corporate performance. Journal of Finance 49: 1010-1040. https://doi.org/10.1111/j.15406261.1994.tb00086.x.

Pranowo K, Achsani NA, Manurung AH, Nuryartono N. 2010. Determinant of corporate financial distress in an emerging market economy: empirical evidence from the indonesian stock exchange 2004-2008. International Research Journal of Finance And Economics. 52: 80-88.

Salehi M, Abendini B. 2009. financial distress prediction in emerging market: empirical evidences from Iran. Business Intelligence Journal 2(2):398409.

Sarlija N, Jeger M. 2011. Comparing financial distress prediction models before and during recession. Croatian Operational Research Review 2:133142.

Shah AA, Rehanakouser AM, Saba I. 2012. Empirical analysis of long and short run relationship among macroeconomic variables and karachi stock market: an Auto Regressive Distributive Lag (ARDL) approach. Pakistan Journal Of Social Sciences 32(2): 323-338.

Steven L. 2011. Faktor-faktor yang memengaruhi kebijakan hutang perusahaan manufaktur. Jurnal Bisnis dan Akuntansi 13(3): 163-181.

Sze CW. 2004. A macroeconomic study of the major determinants of retail rents in Hong Kong [disertasi]. Hongkong: The University Of Hong Kong.

Waluyati LR, Nugroho AD, Pertiwi WN, Mareta Z, Setyaningsih NN, Deltu SN, Putri AZ, Meinardi T. 2015. Agribisnis Kedelai: Antara Swasembada dan Kesejahteraan Petani. Prosiding Seminar Nasional Dies Natalis XVI Magister Manajemen Agribisnis Universitas Gadjah Mada. Indonesia: Magister Manajemen Agribisnis Universitas Gadjah Mada.

Yuliastary EC, Wirakusuma MG. 2014. Analisis financial distress dengan metode $\mathrm{Z}$-score springate, springate, zmijewski. E-Jurnal Akuntansi Universitas Udayana 6(3):379-389. 